\title{
Physical Integrity and Latest Legislative Changes in Albania
}

\begin{abstract}
SUMMARY
In 2016 Albania went through a major justice reform which provided legislative changes to the already existing institutions, established new ones and sought to improve the procedural guarantees of the accused in criminal trials. While the Albanian Code of Criminal Procedure prior to the changes did not provide for biological evidence or a medical intervention in the course of a criminal investigation, the new legislative changes introduced the concepts of biological evidence and the compulsory physical examination as part of tools in search of the evidence. Even though the draft amendments to the previous Albanian Code of Criminal procedure recognized the problems encountered in practice during the collection of biological evidence vis à vis individual's rights to personal integrity and dignity, the application of the newly introduced and enacted provisions remains still unclear and raises concerns, not only regarding the possible arbitrary use of such tools by law enforcement authorities, but also on the possible conflicts that can arise from the application of such procedures by medical examiners and physicians and the fundamental rights of the person under examination or undergoing the medical procedure/intervention.
\end{abstract}

Keywords: bodily integrity, biological evidence, ethics, medical procedure, law, Albania.

\section{The new legislative changes of Albanian Code of Criminal Procedure (ACCP)}

In 2016 Albania went through a much needed justice reform, ${ }^{1}$ with the help of international partners such as EURALIUS mission in Albania, OPDAT, the

\footnotetext{
* Constitutional Court of Albania, Tirana, Albania.

*** General Prosecution of Albania, Tirana, Albania.

**** Faculty of Dental Medicine, University of Tirana, Tirana, Albania.

Correspondence Address: Brunilda Bara, Constitutional Court of Albania, Blvd. "Dëshmorët e Kombit", Nr.26, Tirana, Albania. E-mail: bruna.bara@gjk.gov.al.

1 In order to fight corruption in the country and enhance judicial integrity and independence.
} 
European Parliament, and the Council of Europe. ${ }^{2}$ The reform provided legislative changes to all codes of the Republic of Albania, the Code of Criminal Procedure (ACCP) included. ACCP was further changed in $2017 .{ }^{3}$ Such changes amended the existing provisions on examination of persons, as well as introduced new provisions on collection of biological evidence and compulsory medical procedures, as part of tools in search of evidence in criminal proceedings. ${ }^{4}$

Collection of biological evidence and compulsory medical procedures were new to Albania's criminal system and generated debate among lawyers and medical professionals, due not only to the fact that they belong strictly to individual's personal sphere, but also due to the fact that while the draft-amendments specifically stated what was to be considered as biological evidence, they were not accepted by the legislator and the approved provisions were far more general. ${ }^{5}$

According to the draft-amendments, the legal provisions in force presented a problem vis à vis individual rights and freedoms, their application by law enforcement agents violated individuals fundamental rights such as personal freedom, right to life

2 The reform started in 2014 as part of country's efforts to European integration.

3 Law no.35/2017, dated 30.03.2017 "On several changes and additions to law no.7905, dated 21.03.1995 "Code of Criminal Procedure of Albania”, entered in force on 31.07.2017.

4 ACCP, Chapter III, Section I "Examinations", Article 199: "Examination of persons. 1. The examination is conducted in appropriate locations, in respect, to the extent possible, to the dignity and integrity of the person under examination. 2. Before the examination takes place, the person to be examined is notified on his/her right to request the presence of a person of his/her trust, provided that such person can be quickly found and is suitable. 3. With the consent of the person the examination can be conducted even by a doctor. In such cases proceeding authorities may not take part in the examination. If consent is not granted or the person is a minor, the examination shall be conducted following the procedures provided for in Article 201/a of this Code". Meanwhile, Article 201/a of ACCP provides: "Compulsory collection of biological samples or performance of other compulsory medical procedures. 1. Compulsory collection of biological samples from a defendant or other persons, or performance of a compulsory medical procedure can only be conducted in accordance with the provisions of this article. 2 . The prosecutor, with the consent of the defendant or other persons, can request the collection of biological samples, for the purpose of establishing the DNA profile. Same provisions are applied on the performance of medical procedures. 3. Consent is given in writing. The person whose sample will be taken or will be subject to a medical procedure, signs in the presence of the prosecutor a declaration consenting and confirming on being notified on the reason for the collection of the biological sample or performance of the medical procedure. 4. Such consent for minors is given by the parent or the legal guardian. 5. Upon request of the prosecutor, the court can decide for biological samples or medical procedures to be taken or conducted without the consent of the person and, if necessary limiting his freedom, if no danger comes to his health and if necessary to prove the evidence. Medical procedures that threaten the life of the person, his physical integrity or health, that may harm the unborn child or which, according to medical protocols, may cause illegitimate pain. ...". "12. When the biological sample or medical procedure is collected or performed on the suspect or the defendant, his/her defence lawyer's presence is obligatory. 13. In case of collection of biological evidence or performance of a medical procedure on a minor, the presence of his/her parent, legal guardian or trusted person is obligatory. 14. Results of analysis of biological samples or medical procedures collected contrary to the provisions of this article cannot be used." Article 201/b of ACCP provides for the destruction of the biological samples collected. <https://euralius.eu/index.php/en/library/ albanian-legislation/send/11-criminal-procedure-code/172-criminal-procedure-code-en>, accessed 04.02.2019.

5 Report regarding changes and additions to Albanian Code of Criminal Procedure <https://www.parlament. al/wp-content/uploads/2017/01/RELACION-SHTESA-E-NDRYSHIME-7905-KODI-I-PROCEDURESPENALE-Resized.pdf>, pp. 15-17, accessed 25.04.2018. 
and physical integrity guaranteed by the Constitution of Albania, ${ }^{6}$ the European Convention on Human Rights (The Convention), ${ }^{7}$ or ACCP itself ${ }^{8}$; the provisions were vague or simply there were no provisions on such medical procedures. Therefore new legal provisions were necessary. ${ }^{9}$

While the provisions previously in force recognised the use of force by the proceeding authority for the collection of blood samples and the right of such authority to interference with an individual's bodily integrity, they were considered by the High Level Expert Group ${ }^{10}$ of the Justice Reform as contradictory to the case-law of the European Court of Human Rights (ECtHR). In this regard, the draft amendments aimed to provide exactly the types of DNA samples that could be collected: hair, skin, swabbing buccal cells, saliva, blood, and urine. They also provided for individual's consent to be taken prior to collection or performance of any medical procedure. In cases of no consent it would be up to the courts to decide on the matter. In no case such procedures could be undertaken or performed in such a way that could cause harm to the life of the person, or unwanted suffering.

Referring to case Jalloh v. Germany of ECtHR, ${ }^{11}$ the draft amendments recognised that even where it is not motivated by reasons of medical necessity, Articles 3 and 8 of the European Convention on Human Rights do not prohibit recourse to a medical procedure in defiance of the will of a suspect, in order to obtain from him evidence of his involvement in the commission of a criminal offence. Thus, the taking of blood or saliva samples against a suspect's will in order to investigate an offence would not necessarily breach these Articles.

Meanwhile, the enacted provisions did not provide what sort of biological evidence could be collected. Even though the new provisions ${ }^{12}$ (permitting interference with individual's right to personal freedom and physical integrity, through bodily examination and medical procedures for investigation purposes in search of

6 Article 25: "No one shall be subject to torture or punishment or inhuman or degrading treatment".

7 Article 3: "No one shall be subject to torture or to inhuman or degrading treatment or punishment".

8 Article 5/2 "Limitations to individual's freedom - No one shall be subject to torture, punishment or degrading treatment". Article 8/a "Evidence - 1. Facts and circumstances to the case are proved through evidence collected in respect to individual's fundamental rights and freedoms".

9 Article 199, paragraph 4 of ACCP in force prior to the changes in 2017: "If necessary to ascertain facts important to the case, blood samples or other bodily interventions can be taken or conducted without the person's consent, if they do not present a threat to his/her life".

10 Group of experts (from different fields of expertise) set up by the special parliamentarian committee in order to analyse the situation of the justice system in the country, define justice reform objectives and propose necessary constitutional and legal amendments to achieve them.

11 [GC] Application no.54810/00, pp. 70.

12 Law no.35/2017, dated 30.03.2017 "On several changes and additions to law no.7905, dated 21.03.1995

"Code of Criminal Procedure of Albania"”, entered in force on 31.07.2017. 
evidence) were considered by some as in accordance with the case-law of ECtHR as the interference would be foreseeable and the individual would have access to such legal provisions (through ACCP), ${ }^{13}$ in our opinion, although the legislative changes were necessary, they remain very broad, can be arbitrary used by state authorities and could result in conflicting interests between law enforcement agents, the person performing the collection of biological evidence or medical procedure, and the fundamental rights of the person subject to such procedures.

Referring to the Italian Code of Criminal Procedure (ICCP) in this regard, ${ }^{14}$ Article $247 / 1$ provides that when there is reasonable ground to believe that someone conceals, within its body, evidence of the offense or things pertaining to the crime, a personal search is conducted. Meanwhile, Article 349 of ICCP provides for the collection of hair and saliva as biological evidence, ${ }^{15}$ while Article $359 /$ bis specifically provides collection of biological evidence on living persons.

The French Code of Criminal Procedure (FCCP) provides that biological evidence can be collected only in regard to specific criminal offenses (crimes of a sexual nature, crimes against humanity, acts against the life of a person, torture, drug trafficking, etc.) and not any offense. ${ }^{16}$ According to FCCP, for the examination to be carried out, the judicial police officer may request any authorized person (as provided by Article 16-12 of the Civil Code), without being necessary for such person to be included in a list of forensic experts. Such person then sets in writing the oath (provided for in the second paragraph of Article 60 of the present Code) ${ }^{17}$ Moreover, FCCP provides that in cases of refusal to undergo the collection of biological evidence the person is punished by one year imprisonment or a fine up to 15000 Euros, or in case of serious offences by two years' imprisonment or 30000 Euros fine. ${ }^{18}$

13 Comments on the Albanian Code ofCriminal Procedure, Electronic Commentary, <http://komentarielektronik. magjistratura.edu.al/sq/eli/fz/2017/7905/201-a $>$, accessed 04.02.2019. The Comments referred to cases Kruslin $v$. France, Application no.11801/85 and Huvig v. France, Application no.11105/84 of the ECtHR which concerned interception of communications and not individual's personal physical rights.

14 Chapter III, Section I of ICCP, similar to ACCP. ACCP was enacted based on the Italian Code of Criminal Procedure and the majority of legal provisions are the same.

15 Article 349 of ICCP: "1. Judicial police conduct the process of identification of the person against whom investigations are being carried out as well as persons able to refer relevant circumstances to the reconstructions of the facts. 2. The identification of the person against whom investigations are being conducted can be carried out through, where necessary, use of dactyloscopic, photographic and anthropometric means as well as others. 2-bis. If the use of other means, as provided in the second paragraph requires the extraction of hair or saliva without individual's consent, judicial police can proceed to the compulsory collection, which must be conducted in respect to the dignity of the person undergoing such procedure, upon prior written authorization or orally made and confirmed in writing of the prosecutor".

16 Article $706-55,2^{\circ}$.

17 Article 706-56.

18 Ibid. 
The Albanian Code of Criminal Procedure does not provide neither any limitations regarding the offences for which a person can be subject to the collection of biological evidence or medical procedure, nor, like ICCP or FCCP do, authorities' obligation to present justifiable reasons for such procedures to be performed, or any punishment by way of fine for refusing to undergo the collection of biological evidence or examination.

\section{Legal and ethical problems arising from the application of the new provisions}

The new provisions in ACCP raise many legal and ethical issues not only for lawyers and law enforcement authorities, but also for legal medical examiners as well doctors, nurses or other medical staff who might be involved in such processes.

First, the new provisions, ${ }^{19}$ contrary to the draft amendments which specifically provided what was to be considered biological evidence, do not state what will be considered as such. However, it can be assumed that in this regard one could look at general classifications for biological evidence. ${ }^{20}$

Second, Article 201/a does not provide the category of persons who can perform the procedures (collection of biological evidence or medical procedure), whether the procedures shall be performed by forensics, police officers, judicial police officers, the prosecutor, all of them or just the prosecutor; it does not provide what sort of evidence can be collected, the means to extract such evidence, how such evidence should be administered and the measures taken for the evidence to remain intact; whether such evidence can be collected for any criminal offenses or only specific ones, etc. ${ }^{21}$ As many sources of DNA can be identified such as: sweat, skin, blood, tissue, hair, dandruff, skin, mucus, semen, earwax, saliva, vaginal or rectal cells, and urine, ${ }^{22}$ it becomes unclear the collection of which evidence will be considered as in respect to human dignity and physical integrity. Can collection of blood, semen, vaginal or rectal cells be considered as such by ACCP? Would collection of such evidence be considered acceptable or intrusive?

While ACCP only provides that the prosecutor can request the collection of the biological sample or performance of the medical procedure, it does not provide

19 Law no.35/2017, dated 30.03.2017 "On several changes and additions to law no.7905, dated 21.03.1995 "Code of Criminal Procedure of Albania" amended", in force today.

20 <https://www2.le.ac.uk/departments/genetics/jeffreys/explained>, accessed 28.05.2018.

21 In Albania there were cases where the biological evidence was collected in small unzipped plastic bags.

22 Rolando V. del Carmen, Criminal Procedure Law and Practice, $8^{\text {th }}$ Edition, Wadsworth, Cengage Learning Publishing (2010), p. 325. 
whether this should be performed by an authorized person, the formal procedures to be followed, whether the person carrying out the procedures should be officially registered in a list of judicial experts, ${ }^{23}$ or whether in specific cases, it can even be a doctor.

As regards the medical procedure, it is not a simple one that any person can carry out, such as p.ex. collection of hair or saliva. Such procedures do not necessarily require a particular set of skills. ${ }^{24}$ ACCP refers to a procedure of a medical nature. While it can be assumed that in most of the cases the biological evidence or medical procedure can be collected or performed by a medical examiner, specific cases may need the help and intervention of professional doctors. As such, conflict of interests may arise. In this regard, Article 199 of ACCP provides that examination of persons can be performed by a doctor only with the consent of the person subject to examination, while Article 201/a provides that collection of the biological evidence or a medical procedure can be performed even without person's consent. ${ }^{25}$ As a general rule only persons with an acceptable medical background and who are licensed as a "physician" are entitled to do so. Their educational background should be a guarantee of their skills in making the most accurate diagnosis of an individual case, without exposing the person concerned to unnecessary risks or causing avoidable injuries. At the same time professional codes oblige physicians to exercise the greatest possible care within the physician-patient relationship. ${ }^{26}$

Third, the law does not provide what "the medical procedure" implies. What should be considered as such according to the provisions of ACCP, can any medical procedure be performed, will it affect individual's rights and freedoms? While the law provides that medical procedures that threaten the life, the physical integrity or the health of the person subject to the collection of the biological sample or medical procedure, that can harm the unborn child or which, according to medical protocols can cause illegitimate pain, cannot be performed, it does not explain what is to be understood by "medical procedure". Can a "medical procedure" be invasive to one's body or are they only external physical procedures? ${ }^{27}$ Is a forced medical procedure following

23 Code of Criminal Procedure of France, Articles 706-54 - 706-56.

24 It can be argued however that collection of saliva requires special techniques, <https://www.salimetrics.com/ saliva-collection-handbook/\#saliva-collection-devices-for-adults $>$, accessed 11.02.2018.

25 Upon a court order or by an order of the prosecutor who within 48 hours must present to the court a request on the legality of such order.

26 <http://archive.unu.edu/unupress/unupbooks/uu08ie/uu08ie0t.htm>, accessed 28.05.2018.

27 Code of Criminal Procedure of Italy, Article 247: "When there is reasonable ground to believe that an individual conceals on him/herself material evidence relevant to the criminal offence, physical searches can be performed. ...". Article 249: "The physical search is executed in respect to the dignity, and to the extent possible, the modesty of the person subject to it".

In 2008, for the first time in history, a "brain scan" was relied on as evidence by the Indian state of Marahashtra on the criminal guilt of Aditi Sharma, convicted for the murder of her former fiancé. Brian Farrell, Can't Get You Out 
society's best interests? Is using force to perform a medical procedure right? Does it threaten individual's physical or mental integrity? What if the person is innocent? Is use of such force considered interference to one's right to physical integrity and private life according to Article 8 of the European Convention on Human Rights $(\mathrm{ECHR}){ }^{28}$ What are the legitimacy and proportionality of the interference with regard to individual's right to private life and physical integrity?

While the results of medical investigations may have important evidentiary uses, some techniques are not merely embarrassing but highly invasive and painful. They carry risks to suspects' health. ${ }^{29}$ In Y.F. V. Turkey, ${ }^{30}$ where the applicant complained against forced gynaecological examination towards his wife, ECtHR held that: "Article 8 is clearly applicable to these complaints, which concern a matter of "private life", a concept which covers the physical and psychological integrity of a person.... A person's body concerns the most intimate aspect of private life. Thus, a compulsory medical intervention, even if it is of minor importance, constitutes an interference with this right. ... There has accordingly been an "interference by a public authority" with the right of the applicant's wife to respect for her private life. ... Such an interference will violate Article 8 of the Convention unless it is "in accordance with the law", pursues one of the legitimate aims set out in the second paragraph of that Article, and can be considered "necessary in a democratic society" in pursuit of that aim. ${ }^{31} \mathrm{~A}$ restriction on a Convention right cannot be regarded as necessary in a democratic society - two hallmarks of which are tolerance and broadmindedness - unless, amongst other things, it is proportionate to the legitimate aim pursued. ${ }^{32}$ - Any interference with a person's physical integrity must be prescribed by law and requires the consent of that person, and even minor medical treatment against the patient's will must be regarded as an interference with the right to respect for private

of My Head: The Human Rights Implications of Using Brain Scans as Criminal Evidence, Interdisciplinary Journal of Human Rights Law, Volume 4, (2009-2010), p. 89. In comparison, can or should a "brain scan" be considered part of a medical procedure that can be performed on an individual by Albanian law enforcement agents, within the meaning of Article 201/a of ACCP?

28 Norrgard, K. Forensics, DNA fingerprinting, and CODIS, Nature Education, Volume 1, Issue 1, (2008), p. 35, accessed at <https://www.nature.com/scitable/topicpage/forensics-dna-fingerprinting-and-codis-736> on 28.05.2018, which states: "Forced DNA Profiling. ... Retention of an innocent person's DNA can be seen as an intrusion of personal privacy and a violation of civil liberties. It is interesting to note that in the United States, under any other circumstance, the provision of a DNA sample would require informed consent and other protections for the donor."

29 Jack Tsen-Ta Lee, Medical Investigation of Suspects by the Police, Singapore Management University, Research Collection School of Law, (1996), p. 53, < https://ink.library.smu.edu.sg/cgi/viewcontent. cgi?article=1592\&context=sol_research $>$, accessed 11.02.2019.

30 Application no. 24209/94.

31 Ibid, pp. 32-36.

32 Acmanne and others v. Belgium, Application no. 10435/83. The case concerned parents and teachers who refused to submit their children or pupils to forced examination tests for tuberculosis through tuberculin skin reaction tests or chest $\mathrm{x}$-rays. 
life. - Otherwise, a person in a vulnerable situation, such as a detainee, would be deprived of legal guarantees against arbitrary acts. ${ }^{33}$

Fourth, the new legal provisions of ACCP provides that not only the defendant but also other persons can be subject to collection of biological evidence or performance of medical procedures, broadening the group of people that can be affected. As a general rule, the person subject to medical examination can be the accused, a person under investigation, or a person claiming to be a victim of a criminal offence. As a result, in cases of collection of evidence by medical professionals it becomes difficult to establish whether the person subject of the examination should or should not be considered a patient. While the accused or a person under investigation is not considered as patient during medical legal examination, a victim, such as p.ex. sex assault victim can also be a patient. Physicians in such cases are responsible for both the health care of sexually assaulted persons and for conducting forensic medical examinations on them for the purpose of collecting corroborative evidence to aid in legal proceedings. ${ }^{34}$ General ethical rules should apply in both cases. Therefore, the interference through collection of biological evidence or performance of a medical procedure, as provided by ACCP, to individual's fundamental rights raises concerns on the conflicting interests, rights and duties of the physicians obliged to perform such procedures. Considering that all physicians must obey to the Hippocratic Oath which appeals to a sort of "primum non nocere" and benefiting of patient's principles, introduced in physicians', nurses', doctors', as well as medical examiners' ethical codes of countries, the fiduciary nature of the doctor-patient relationship is based on trust. In medicine, a doctor trusts that the patient will open up to him/her, and in return the patient trusts that the doctor will respect and use the information for his/her benefit. The values that the physician should seek to promote are therefore entrenched in the tradition of medicine. As a result, the duties of a physician can be derived from the rich tradition of practice of medicine, such as relieving suffering. ${ }^{35}$

Thus, ACCP doesn't answer many questions: Can or should the person subject to a medical procedure or intervention be considered a patient? Who should perform such procedures? In cases when the person strongly resists the collection of biological evidence, or the performance of a medical procedure, will the exercise of force by law enforcement agencies or physicians be justifiable? If so, how much force can be justified? What if the examination can only be conducted in the presence of other

\footnotetext{
33 Ibid, pp. 43.

34 Du Mont J., Pamis D. The doctor's dilemma: caregiving and medicolegal evidence collection, Medicine and Law, Volume 23, Issue 3, (2004), pp. 515-29.

35 Sipho Michael Lukhozi, Dual obligations in clinical forensic medicine, Master thesis, Stellenbosch University, April $2014<$ https://scholar.sun.ac.za/bitstream/handle/10019.1/86537/lukhozi_dual_2014. pdf?sequence $=1$ \&isAllowed $=y>$, accessed 07.02.2019, p. 30 .
} 
people? How would this affect one's dignity? How should the medical examiner or the doctor act in similar situations? Can they refuse to examine? What consequences would this bring upon them? Will the refusal be considered as failure to obey the order of an official?

\section{Conflicting rights and duties and EctHR case-law}

If during the performance of the medical procedure provided by Article 201/a of ACCP the person is to be considered a "patient" the job of the physician becomes more difficult. On one hand the doctor must respect patient's rights, on the other he needs to obey the orders of the authorities, while at the same time considering his ethical duties.

"Primum non nocere" principle, also known to health care providers as the principle of non-maleficence, forms an important part of today's deontological ethics and is focused on patient's best interest. However, a clear definition of patient's interest is often difficult. This is due to the fact that not always what health care providers conceive of as the best for the patient complies with the wishes of the latter. Nowadays special attention is paid to the right of the patient to self-determination and bodily integrity. The idea of autonomy of the patient was first mentioned in the International Code of Medical Ethics, ${ }^{36}$ adopted in 1949. This Code emphasized the obligation of a healthcare provider to respect the right of a mentally and wellinformed patient to accept or refuse treatment. The essence of this right lies in the fact that a competent and well-informed patient has the right to self-determination regarding medical treatment, even if this contradicts his best interest in a professional medical outlook. ${ }^{37}$ Over himself, over his own body and mind, the individual is sovereign. ${ }^{38}$ The modernist notion of bodily integrity structures intersubjective relations and is more apparent in moments of challenge, such as consent for medical care, criminal evidence collection, and reproductive issues, such as forced pregnancies or abortions. ${ }^{39}$

For healthcare providers this means not only respecting the patient's right to selfdetermination, but at the same time creating the necessary conditions for autonomous choice through informing the patient of all possible treatment options, a clear and

36 <https://www.wma.net/policies-post/wma-international-code-of-medical-ethics/>, accessed 26.05.2018.

37 Lars Sandman, Bradi B. Granger, Inger Ekman, Christian Munthe, Adherence, shared decision-making and patient autonomy, Medical Health Care Philosophy Journal, Volume 15, Issue 2, (2012) pp. 115-127.

38 John Stuart Mill, On Liberty, 1859, p. 13, <https://eet.pixel-online.org/files/etranslation/original/Mill,\%20 On\%20Liberty.pdf>, accessed 24.05.201.8

39 Neil Gerlach, Sheryl N. Hamilton, Rebecca Sullivan, Priscilla L. Walton, Becoming Biosubjects: Bodies, Systems, Technologies, University of Toronto Press (2011), p. 8. 
understandable explanation of the risks of intervention, ensuring that the patient has well understood them and his consent to all procedures before medical intervention. ${ }^{40}$

In many countries, health care providers can consciously object the performance of a medical procedure if it conflicts their ethical values. Conscientious objection is defined as the request, inspired on religious or ethical convictions, of a private exemption that allows the objector to avoid an ordinary duty or to carry out an action prohibited by the law. It is a private act, designed to protect the agent from interference by public authority. ${ }^{41}$ Such fundamental right derives from the free exercise or freedom of conscience. If a conflict arises between rights, conscientious objection should yield in favour of the higher ranked right. ${ }^{42}$

The issue becomes more problematic in cases of non-consensual interventions by health care providers to an individual's physical integrity due to an order given by state authorities. ${ }^{43}$ Non-consensual interventions from competent individuals raise a series of challenging ethical questions regarding both unwanted medical interventions and the role of health professionals: Do such interventions violate the fundamental human and Constitutional rights to bodily integrity? Are physicians and other health care providers bound to participate in forced procedures as part of their professional duty to serve the public welfare? Or are these providers forbidden to participate as part of their professional obligation to respect patient autonomy and to do no harm? ${ }^{44}$ While the arrest of medical providers for refusing non-consensual procedures remains a rare event, conflicts between clinicians and law enforcement will continue to arise in circumstances where either providers are uncertain of their legal duties or where their legal duties conflict with perceived ethical obligations to their patients. ${ }^{45}$

Meanwhile, if the medical procedure provided by ACCP is to be performed by a medical examiner, his role in the course of criminal proceedings would be similar to that of an expert witness, who, according to the provisions of ACCP must be sworn

40 Protection of the right for autonomy of an Albanian patient is provided by Article 5 of the Albanian Charter of Patient's Rights, enacted by Decision no. 657, dated 15.02. 2010 of the Minister of Health, <http://www. shendetesia.gov.al/files/userfiles/KARTA_SHQIPETARE_E_TE_DREJTAVE_TE_PACIENTIT_e_miratuar. pdf>, accessed 24.05.2018; Article 28 of Code of Ethics and Medical Deontology; Article 4/3 of Nurse's Code of Ethics and Deontology; Law no.138/2014, Article 4/a "On palliative care in the Republic of Albania"; acts these that enshrine the principles set out in the Hippocratic Oath, which the physicians are obliged to take.

41 Soledad Bertelsen, Conscientious Objection of Health Care Providers: Lessons from the Experience of the United States, Notre Dame Journal of International \& Comparative Law, Volume 3, Issue 1, (2013), pp. 124-125.

42 Ibid, p. 126.

43 Kristin E. Malcolm, James G. Malcolm, Daniel T. Wu, Kevin A. Spainhour, Kevin P. Race, Cops and docs: The challenges for ED physicians balancing the police, state laws, and EMTALA, Journal of Healthcare Risk Management, Vol 37, No 2, (2017), p. 29 <https://www.insleyrace.com/Cops-and-Docs.pdf>, accessed 07.02.2019.

44 Jacob M. Appel, Nonconsensual Blood Draws and Dual Loyalty: When Bodily Integrity Conflicts with the Public Health, Journal of Health Care Law and Policy, Volume 17, Issue 1, (2014), p. 130.

45 Ibid, p. 131. 
in before conducting any examination and will be held responsible and punished for false testimony in case of untrue or misleading statements on the facts of the case. ${ }^{46}$ He must also be independent from any pressure from the government as well as impartial.

Many studies have emphasized that clinical forensic medicine is a discipline that is not based on the traditional doctor-patient relationship. It is a field not primarily focused on the well-being of patients. It is mainly concerned with "the application of medical knowledge to the adjudication of legal disputes, both criminal and civil". Hence the traditional medical ethics based on trust and fiduciary nature of doctorpatient interaction is not central in clinical forensic medicine. Clinical forensic medicine's main objective is the administration of justice. As such, clinical forensic medical assessments ought to be carried out in an objective, fair and impartial manner. Often, two or more parties involved in a dispute have competing interests. On the one side, the suspect may desire not to have incriminating evidence or information revealed to the police by the medical examiner, whilst on the other hand, the police and/or prosecution may desire to obtain evidence or information that will prove a certain allegation. To this end, the police may attempt to secure evidence in a manner that undermines the suspect's rights. A medical examiner must not favour any of these sides during his work, and ought to conduct his or her duties in an objective and fair manner. ${ }^{47}$

Consequently, during a physical search, collection of biological evidence or performance of a medical procedure, due to the very nature of his work, the medical examiner carries a heavier burden than that of a doctor. He must strike a balance between the duty to perform the examination and administer justice, the pressure from the prosecuting authorities and the ethical duty to guarantee the rights of the person under examination. It is upon him to decide what sort of interference amounts to a violation of the dignity and integrity of the person under examination. ${ }^{48}$

As stated by ECtHR case-law, interferences to the right to respect for private life must be in accordance with the law, necessary in a democratic society and in the interests of national security, public safety or the economic well-being of the country, for the prevention of disorder or crime, for the protection of health or morals, or for

46 Article 306 of the Albanian Criminal Code.

47 Sipho Michael Lukhozi, Dual obligations in clinical forensic medicine, Master thesis, Stellenbosch University, April 2014 < https://scholar.sun.ac.za/bitstream/handle/10019.1/86537/lukhozi_dual_2014. pdf?sequence=1\&isAllowed $=y>$, accessed 07.02.2019, p. 15 .

48 Article 4 of the Code of Legal Medical Ethics of Albania provides: "The legal medical examiner should focus his mission in serving and assisting justice, providing the same forensic expertise for all, regardless of age, sex, race, nationality, religion, political affiliation, economic status, social status etc., while at the same time respecting the human rights and dignity of each individual". 
the protection of the rights and freedoms of others. ${ }^{49}$ As such, the intervention/the measure can be justifiable only if is founded on a legal provision, serves a legitimate aim, is proportional, and fulfils a pressing social need.

While in some cases the intervention of the state in one's fundamental rights and freedoms can be justified, in cases of health care providers there are conflicting rights and duties that affect their decisions. Even if state authorities order them to conduct an examination, the application of their ethical principles and values to the case could result in a conflict, especially in cases where use of force is required to conduct the examination. How should physicians act in such cases? Would their refusal to examine be justifiable? Which authority would be responsible to take action against a doctor's refusal to perform a medical examination? Would it be the authority who ordered the medical procedure or examination, the court, or the institution/hospital were the doctor exercises his duties?

According to ECtHR case-law, various guarantees are provided against arbitrary examinations. In cases of p.ex. forced blood testing examinations regarding DWI ${ }^{50}$ cases, ... a blood test may only be ordered by an official authorised to do so and may only be performed by an approved doctor, who may ... refuse to carry out the test for exceptional reasons of a medical character. ${ }^{51}$ In respect of Article 8 of the Convention, a compulsory medical intervention, even if it is of minor importance, must be considered an interference with the right to respect for private life. Therefore, the obligation to undergo a urine test constitutes an interference with the right to respect for the private life within the meaning of Article 8 para. 1 of the Convention. However, such interference can be justified for the prevention of disorder or crime. The "prevention of disorder or crime" may justify wider measures of interference in the case of a prisoner than in that of a person at liberty..$^{52}$ Medical examination of a detainee by a forensic doctor can also prove to be a significant safeguard against false accusations of sexual molestation or ill-treatment. ${ }^{53}$ Nevertheless, injection of emetics, through use of force verging on brutality amount to inhuman and degrading treatment due to the grave interference with individual's physical and mental integrity against his will, causing pain, anxiety and mental suffering. Alternative measures, such as waiting for the drugs to pass out of the body naturally, although could entail some invasion of privacy because of the need for supervision, involve a natural bodily

49 ECHR, Article 8/2.

50 Driving while intoxicated.

$51 X v$. the Netherlands, Application no. 8239/78, pp. 184.

52 Peters v. the Netherlands, Application no. 21132/93.

53 Y.F. v. Turkey, Application no. 24209/94, pp. 43; Devrim Turan v. Turkey, Application no 879/02, pp. 20. 
function and so cause considerably less interference with a person's physical and mental integrity than forcible medical intervention. ${ }^{54}$

\section{Conclusions}

While the new changes to Albanian Code of Criminal Procedure follow a legitimate aim and were necessary to guarantee the fundamental rights of people subject to physical searches, they need further reviewing. Many problems consist on the proportionality of the measures provided by the legal provisions, the authorities involved and the guarantees offered to individuals subject to such procedures. The revised provisions must be clear and precise in order to prevent any arbitrary use of power by state authorities. They must provide the procedural steps to be followed for the collection of evidence, what a medical procedure entails, what kind of biological evidence can be collected, the persons in charge to collect such evidence or to perform the medical procedure, the rights of physicians or medical examiners to refuse if the procedures conflict with their ethical values.

Furthermore, the request that the prosecutor files with the court for the collection of the biological evidence or performance of the medical procedure, must present an objectively reasonable basis on why such procedures are indispensable to the investigation and why no other alternative methods exist to discover the evidence. The judge permitting the procedure must, in the presence of conflicting scientific opinions on the possible results of the collection of biological evidence or performance of the medical procedure, ${ }^{55}$ provide an adequate and exhaustive justification for the reasons why it accepts the request.

While collection of biological evidence or performance of a medical procedure can be important tools for the administration of justice, state authorities must also take into consideration not only that any recourse to a forcible medical intervention, in order to obtain evidence of a crime, must be convincingly justified on the facts of the particular case but also any alternative methods of recovering the evidence through procedures that do not entail any risk of lasting detriment to a suspect's health. ${ }^{56}$

The particularly intrusive nature of an act, such as p.ex. retrieving from inside the individual's body real evidence of the very crime of which he is suspected, requires a strict scrutiny of all the surrounding circumstances. In this connection, due regard must be had to the seriousness of the offence in issue. The manner in which a person

54 Jalloh v. Germany, [GC] Application no. 54810/00, pp. 79.

55 Rolando V. del Carmen, Criminal Procedure Law and Practice, $8^{\text {th }}$ Edition, Wadsworth, Cengage Learning Publishing (2010), p. 326

56 Ibid, Jalloh v. Germany, pp. 71. 
is subjected to a forcible medical procedure in order to retrieve evidence from his body must not exceed the minimum level of severity prescribed by the ECtHR's caselaw on Article 3 of the Convention. In particular, account has to be taken of whether the person concerned experiences serious physical pain or suffering as a result of the forcible medical intervention..$^{57}$

Furthermore, ACCP must be accompanied with a set of rules and regulations on the procedures for the collection of biological evidence or performance of a medical procedure and the proper administration of such evidence, in order to get the best results for the investigation, while at the same time guaranteeing the fundamental rights of the person under examination.

\section{Bibliography}

Del Carmen R. V., Criminal Procedure Law and Practice, $8^{\text {th }}$ Edition, Wadsworth, Cengage Learning Publishing (2010).

Gerlach N., Hamilton S. N., Sullivan R., Walton P. L., Becoming Biosubjects: Bodies, Systems, Technologies, University of Toronto Press (2011).

Leino-Kilpi H., Välimäki M., Arndt M., Dassen T., Gasull M., Lemonidou C., Scott P. A., Bansemir G., Cabrera E., Papaevangelou H., Mc Parland J., Patient's Autonomy, Privacy and Informed Consent, IOS Press (2000).

Lukhozi S. M., Dual obligations in clinical forensic medicine, Master thesis, Stellenbosch University, April 2014.

Mill J. S., On Liberty, 1859.

\section{Treaties}

The European Convention on Human Rights

\section{Statutes and statutory instruments}

The Constitution of the Republic of Albania

Albanian Code of Criminal Procedure

Code of Criminal Procedure of France

Code of Criminal Procedure of Italy

Law no.35/2017, dated 30.03.2017 “On several changes and additions to law no.7905, dated 21.03.1995

"Code of Criminal Procedure of Albania"”

Law no.138/2014 "On palliative care in the Republic of Albania"

Decision no. 657, dated 15.02. 2010 of the Minister of Health

57 Peters v. the Netherlands, Application no. 21132/93. 


\section{Ethical Codes}

International Code of Medical Ethics

Code of Legal Medical Ethics of Albania

\section{Journal articles}

Appel J. M., Nonconsensual Blood Draws and Dual Loyalty: When Bodily Integrity Conflicts with the Public Health, Journal of Health Care Law and Policy, Volume 17, Issue 1, (2014).

Bertelsen S., Conscientious Objection of Health Care Providers: Lessons from the Experience of the United States, Notre Dame Journal of International \& Comparative Law, Volume 3, Issue 1, (2013).

Du Mont J., Pamis D. The doctor's dilemma: caregiving and medicolegal evidence collection, Medicine and law, Volume 23, Issue 3, (2004).

Farrell B., Can't Get You Out of My Head: The Human Rights Implications of Using Brain Scans as Criminal Evidence, Interdisciplinary Journal of Human Rights Law, Volume 4, (2009-2010).

Jack Tsen-Ta L. J., Medical Investigation of Suspects by the Police, Singapore Management University, Research Collection School of Law, (1996).

Malcolm K. E., Malcolm J. G., Wu D. T., Spainhour K. A., Kevin P. Race, Cops and docs: The challenges for ED physicians balancing the police, state laws, and EMTALA, Journal of Healthcare Risk Management, Vol 37, No 2, (2017).

Norrgard, K. Forensics, DNA fingerprinting, and CODIS, Nature Education, Volume 1, Issue 1, (2008).

Sandman L., Granger B. B., Ekman I., Munthe C., Adherence, shared decision-making and patient autonomy, Medical Health Care Philosophy Journal, Volume 15, Issue 2, (2012).

Sandman L., Granger B. B., Ekman I., Munthe C., Adherence, shared decision-making and patient autonomy, Medical Health Care Philosophy Journal, Volume 15, Issue 2.

\section{ECtHR case-law}

Acmanne and others v. Belgium, Application no. 10435/83

Acmanne and others v. Belgium, Application no. 10435/83

Devrim Turan v. Turkey, Application no 879/02

Huvig v. France, Application no.11105/84

Jalloh v. Germany, [GC] Application no.54810/00

Kruslin v. France, Application no.11801/85

Peters v. the Netherlands, Application no. 21132/93

$X v$. the Netherlands, Application no. 8239/78

Y.F. V. Turkey, Application no. 24209/94

\section{Websites}

http://archive.unu.edu/unupress/unupbooks/uu08ie/uu08ie0t.htm

http://komentarielektronik.magjistratura.edu.al/sq/eli/fz/2017/7905/201-a

http://www.shendetesia.gov.al/files/userfiles/KARTA_SHQIPETARE_E_TE_DREJTAVE_TE_ PACIENTIT_e_miratuar.pdf

http://www.shendetesia.gov.al/files/userfiles/KARTA_SHQIPETARE_E_TE_DREJTAVE_TE_

PACIENTIT_e_miratuar.pdf 
https://ink.library.smu.edu.sg/cgi/viewcontent.cgi?article=15928context=sol_research

https://scholar.sun.ac.za/bitstream/handle/10019.1/86537/lukhozi_dual_2014. pdf? sequence $=1$ \&isAllowed $=y$

https://www.nature.com/scitable/topicpage/forensics-dna-fingerprinting-and-codis-736

https://www.parlament.al/wp-content/uploads/2017/01/RELACION-SHTESA-E-NDRYSHIME-7905-

KODI-I-PROCEDURES-PENALE-Resized.pdf

https://www.salimetrics.com/saliva-collection-handbook/\#saliva-collection-devices-for-adults

https://www.wma.net/policies-post/wma-international-code-of-medical-ethics/

https://www2.le.ac.uk/departments/genetics/jeffreys/explained

\section{Fizički integritet i najnovije zakonodavne izmjene u Albaniji}

\section{SAŽETAK}

U 2016. godini Albanija je prošla kroz veliku reformu pravosuđa koja je već postojećim institucijama donijela zakonske izmjene, uspostavila nove zakone te nastojala poboljšati procesna jamstva optuženih u kaznenim postupcima. Dok albanski Zakon o kaznenom postupku prije ovih izmjena nije predviđao biološke dokaze niti medicinsku intervenciju tijekom kaznene istrage, nove zakonske izmjene predstavile su koncepte bioloških dokaza i obavezni fizički pregled kao dio alata u potrazi za dokazima.

Iako su u nacrtima amandmana za prethodni Zakon o kaznenom postupku Albanije prepoznati problemi koji se susreću u praksi tijekom prikupljanja bioloških dokaza s obzirom na prava pojedinca na osobni integritet i dostojanstvo, primjena novouvedenih i donesenih odredbi i dalje ostaje nejasna i izaziva zabrinutost, ne samo u pogledu mogućeg proizvoljnog korištenja takvih alata od strane tijela za provedbu zakona, već i zbog mogućih sukoba koji mogu proizaći iz primjene takvih postupaka od strane medicinskih istražitelja i liječnika te temeljnih prava osobe koju se ispituje ili prolazi kroz medicinski postupak/intervenciju.

Ključne riječi: tjelesni integritet, biološki dokazi, etika, medicinski postupak, pravo. 